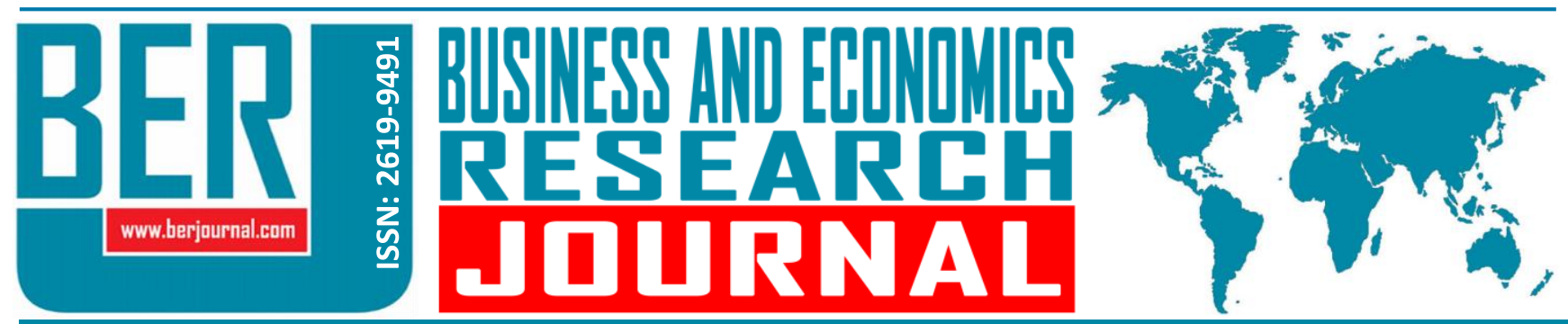

Business and Economics Research Journal Vol. 11, No. 4, 2020, pp. 939-952 doi: 10.20409/berj.2020.291

\title{
The Impact of US Monetary Policy Announcements on Equity Prices: Evidence from Borsa Istanbul
}

\author{
Deniz Ikizlerli ${ }^{\mathrm{a}}$, Haluk Yener ${ }^{\mathrm{b}}$, Burak Alparslan Eroglu ${ }^{\mathrm{c}}$
}

Abstract: This study examines the effect of FOMC's (Federal Open Market Committee) announcements on the volatility of stock returns in the Borsa Istanbul (BIST) from January 4, 2000 to May 31, 2019. We find that FOMC's news increases the market level of volatility on announcement days but cannot find any evidence that it had a destabilizing effect on the Turkish stock market over our observation period. We also look at the effect of FOMC's news on the return volatility of the BIST100 index over different states of the stock market and find that FOMC's announcement days give a lift to conditional volatility both in bull periods and bear periods, but find no evidence of destabilizing impact. On the contrary, both positive announcement and negative announcement shocks in bull periods are found to depress volatility on consecutive days. In other words, FOMC's announcements in bull periods have a stabilizing effect on equity prices rather than a destabilizing in the BIST100 index.

\author{
Keywords: FOMC's (Federal \\ Open Market Committee) \\ Announcements, Stock- \\ Return Volatility, Asymetric \\ Volatility, Emerging Markets \\ JEL: C22, G15

$\begin{array}{ll}\text { Received } & : \text { 10 March } 2020 \\ \text { Revised } & : \text { 04 May } 2020 \\ \text { Accepted } & : \text { 28 September } 2020 \\ & \\ \text { Type } & : \text { Research }\end{array}$

\section{Introduction}

Among all types of information the market participants closely follow, United States (US) monetary policy news is perhaps one of the essential information to follow. This situation is because the US dollar is still the world's first-class reserve currency, which is held in significant quantities by many governments and institutions (Hayo et al., 2012). It is used for major investments, transactions, and international debt obligations. Therefore, the Federal Open Market Committee (FOMC)'s decisions are followed closely not only by market participants in developed countries but also by market participants in emerging countries as well.

Investors in emerging markets are likely to watch FOMC announcements closely due to either emerging markets' trades or financial linkages with the US In essence, with increased global connectivity since the late 1980s, understanding the effect of announcements becomes even more critical (Phylaktis, 2006). This importance stems from a significant impact of FOMC's news on global liquidity conditions, which in turn affects capital flows to emerging markets (See, for example, Chandrashekhar, 2008 and Shin, 2013).

The channels through which Fed (Federal Reserve) policy influences the rest of the world becomes, take many forms. Particularly, the four channels through which US monetary policy announcements may affect emerging countries' asset prices is examined in Wongswan (2009).

Cite this article as: Ikizlerli, D., Yener, H., \& Eroglu, B. A. (2020). The impact of US monetary policy announcements on equity prices: Evidence from Borsa Istanbul. Business and Economics Research Journal, 11(4), 939-952.

The current issue and archive of this Journal is available at: www.berjournal.com

Asst. Prof., PhD., Istanbul Bilgi University, Faculty of Business, Department of Business Administration, Istanbul, Turkiye, deniz.ikizlerli@bilgi.edu.tr (ORCID ID: 0000-0002-3443-8073)

b Asst. Prof., PhD., Istanbul Bilgi University, Faculty of Business, Department of Business Administration, Istanbul, Turkiye, haluk.yener@bilgi.edu.tr (ORCID ID: 0000-0003-2654-5810)

Asst. Prof., PhD., Istanbul Bilgi University, Faculty of Business, Department of Economics, i̇stanbul, Turkiye,

burak.eroglu@bilgi.edu.tr (ORCID ID: 0000-0001-6814-747X) 
The first one is the demand channel theory, which posits that firms producing cyclically-sensitive goods and firms that have trade linkages (through export or import) with the United States may be more prone to the effect of the news on US monetary policy (Wongswan, 2009). According to this channel, shortterm real interest rates are affected by the FOMC's decisions, since prices are sticky, which in turn affect aggregate demand. Higher/lower interest rates encourage US consumers to reduce/increase their current spending, which in turn affects demand for the products of importers to the US.

The second channel is the credit channel, which reflects the fact that firms in emerging markets that have low credit ratings and that depend on external financing may find it challenging to find a bank loan or other loans when credit conditions become tighter (Wongswan, 2009). A change in US interest rates also affects credit supplied by institutions in emerging markets. For example, according to Goldberg (2002), US banks' foreign claims are correlated with real US interest rates. In this vein, it would be natural to expect US monetary policy decisions' effect on the level of credit supplied to the rest of the world, especially emerging markets.

The third channel is the portfolio channel, which suggests that international investors might change their allocations in the emerging markets after a shock in broad markets due to trying to rebalance their stock and bond portfolios across markets (Kodres \& Pritsker, 2002). Notably, international investors might carry a certain percentage of foreign stocks in their portfolios. However, regardless of the type of assets, if their appetite for risk increases or decreases as a result of a Fed funds surprise, the percentage of international investor's portfolios devoted to foreign stocks can also be changed in order to adapt to their new investment plan.

Finally, the underlying theory of the fourth channel, which is the foreign interest rate channel, posits that Fed policy also affects short- and long-term interest rates in emerging countries (Kim, 2001; Hausman \& Wongswan, 2011). This channel is the most crucial channel of transmission since it covers both the demand channel and the credit channel mentioned above concerning domestic consumers and domestic firms, respectively (Wongswan, 2009). Thus, since US monetary policy is thought to influence foreign interest rates, then a natural aim is to look into its effect on stock prices in emerging markets.

In this respect, Fed policy has been documented to be one of the most critical global shock (Ehrmann \& Fratzscher, 2009; Wongswan, 2006, 2009) that affects equity returns in both emerging and mature markets. Since Fed policy is suggested to be a risk factor in global financial markets, this study aims to investigate whether US monetary policy announcements have a destabilizing effect on stock prices in the Borsa Istanbul (BIST).

BIST is the most in-depth and largest equity market in the EEMENA (Eastern Europe, Middle East, North Africa) region, which was ranked 8th among all emerging markets in the world in terms of the total value of shares traded in $2018 .{ }^{1}$ Despite the rank of BIST within the emerging world, a longstanding specific characteristic of the Turkish economy is its low savings rate. Since the 2000s, primarily until the mid of 2018, Turkey has run substantial current account deficits. In the 1990s, while the ratio of current account deficit to GNP was 1\%, it was over $5 \%$ since 2004 (excluding 2009). ${ }^{2}$ For example, in January 2018, the rolling 12-month current account deficit rose to $\$ 51,6$ billion, which was one of the highest current account deficits compare to its GDP in the world.

The contribution of this paper is two-fold. First, analyzing a country like Turkey would provide an opportunity to enrich the literature, since specific characteristics such as political turnovers, persistent high inflation, and relying on foreign capital inflows to finance its wide current account deficit make Turkey different from other developed countries. ${ }^{3}$

Second, we modify the GJR specification of Glosten et al. (1993) to see the asymmetric effect of FOMC announcements on XU100 index returns. ${ }^{4}$ Besides, we also take different states of the stock market into account since the behavior of investors can change during bull and bear market periods (Hardouvelis \& Theodossiou, 2002). For example, Klein and Rosenfeld (1987) document divergent results for the identical events during bull and bear markets. Bowman, Robin, and Weintrop (1995) also find that current underlying 
market conditions (bull/bear markets) influence the event study results. In a similar vein, Docking and Koch (2005) find that investors perceive good (bad) news as better (worse) news when the recent direction of the stock market is down (up) and volatile. Given these findings, it would also be useful to investigate the impact of FOMC's announcements on different conditions of the stock market.

To this end, we measure the effect of FOMC announcements in different phases (i.e., bull/bear market) of the market. Our main findings suggest that while FOMC's announcements have a lifting effect on the conditional volatility of BIST returns, they do not destabilize the index. In effect, during bull periods, FOMC's announcements stabilize the returns in the BIST100 index.

The structure of our paper is as follows: Section 2 provides a review of the literature addressing the issues mentioned above. Our data consist of daily observations of BIST100 index returns extending from the beginning of the year 2000 to the end of the year 2019. Therefore, the last twenty years of returns are covered in the BIST100 index. Section 3 presents the data and outline the methodology employed in this study. There, our GJR specifications are introduced, and the Markov switching model is also presented to capture the bear and bull periods in BIST. After employing the model, Section 4 starts with the preliminary analysis and presents our results. Section 5 concludes by summarizing the main results.

\section{Literature Review}

Sudden reversals of capital inflows can easily lead to financial instability in economies of emerging countries. Hence, the question of what determines these capital flows to emerging countries has received widespread attention in the economics and finance literature. One strand of literature focuses on equity flows and tries to understand key drivers motivating these equity flows to the emerging markets. In this context, one line of research gives particular mention to the role of US monetary policy as a driving factor for international capital flows. Several papers have investigated how US monetary policy affects foreign asset prices.

For example, Wongswan (2009) investigates the effect of the Federal Reserve (Fed) policy surprises on fifteen equity indexes, including both developed and developing countries between 1998 and 2004. Employing high-frequency data, he documents significant evidence of an effect of Fed policy surprises on global equity indexes in short time horizons. He finds that both developed and emerging equity markets incorporate FOMC's news very quickly, which is less than 15 minutes. The study also examines whether FOMC announcements affect foreign equities through cash flow or discount rate components of foreign equities and finds that US monetary policy surprises affect equities in foreign countries through their discount rate component. In a similar vein, Hausman and Wongswan (2011) investigate the relationship between FOMC announcements and global asset prices in forty-nine countries and find that FOMC's decisions are important to global equity markets. Moreover, they examine this relationship with respect to different components of the monetary policy. ${ }^{5}$ The study documents different reactions for different asset classes to the monetary policy surprises. Global equity markets are found to respond to the target surprise, whereas long-term interest rates and exchange rates are found to respond to the path surprise.

Many researchers believe that the tightening of US monetary policy increases the vulnerability of economies in emerging countries (Frankel \& Roubini, 2001). Motivated from this perspective, Robitaille and Roush (2006) investigate how movements in US interest rates (through FOMC's announcements) influence Brazilian asset prices. Specifically, they analyze movements in the Brazilian government bonds and equity index (BOVESPA) in the event of FOMC's announcements between 1999 and 2005. They find that an unexpected rise in US interest rates was associated with a systematic rise in the bond spreads and a decrease in the stock market. Similarly, Valente (2009) examines the reactions of market interest rates to FOMC announcements surprises for the US, Hongkong, and Singapore. He finds that FOMC announcements have a significant effect on the term structure of interest rates in these three countries, but interest rates in Hongkong are found to behave more similar to the interest rate responses in the US compared to the ones in Singapore. 
Some studies investigate the impact of monetary policy decisions on the volatility of asset prices in addition to the level of asset prices. For example Konrad (2009) examines whether monetary policy surprises by the Fed or European Central Bank (ECB) significantly affect the volatility of prices in equity and bond markets in Germany. He finds that while equity return volatility is sensitive to FOMC's decisions, return volatility in bond markets is susceptible to monetary policy surprises in the Eurozone. He also documents larger effects of monetary policy surprises on German equity return volatility in bear market periods when compared with the bull periods. Also, Hussain (2011) examines the effects of monetary policy decisions on the US and major European (Germany, France, UK, and Switzerland) equity indices in terms of price levels and volatilities. He documents significant evidence of immediate impact on equity prices and volatilities in both US and European markets. Moreover, he finds that volatilities in European equity indices are significantly affected by the press conference of ECB, which is held just after the meeting. In a similar vein, Andersen et al. (2007) examine bond and stock market volatility responses in the euro area and the US following monetary policy decisions for the period between January 1992 and December 2002. They find strong upward movements in intraday volatility at the release of the announcements about monetary policies by these two central banks.

Similar issues were also analyzed using the Turkish data set. For example, Koylu and Yucel (2019) examine the relationship between the changes in FED interest rates and daily XU100 index values. To this end, a decision model based on classification and regression tree analysis was utilized. The observation period starts from January 4,1998, and ends on August 6, 2018. The study investigates the relationship for three different periods based on the FED announcements, namely; the following trading day, the following weekly trading period, and the period that includes all trading days until the next announcement. They find that the variation in FED interest rates is only associated with the prices of the weekly trading period, whereas they find no evidence of a relationship for the other two periods. Similarly, Celik et al. (2014) examine the impact of changes in policy rates of The Central Bank of the Republic of Turkey (CBRT) on the volatility of XU100 sessions for the period between 02.01.2002 - 17.02.2014. To this end, a series of changes in the first session, changes in the second session, and changes on the whole day were employed. Using GARCH, EGARCH, TARCH, GJR-GARCH ve APARCH models, the study also carries out the analysis separately for four periods, namely, before, during, and after global financial crises and whole period. In addition, similarly, the study also investigates the effect of the forward guidance of the CBRT, FED, and ECB on the volatility of BIST100 sessions for the period between 18.12.2009 - 17.02.2014. The study finds that an increase in policy rates decreases the volatility of sessions, and forward guidance increases the volatility in the 1 . session and 2. session but decreases the volatility in the whole day. The study also finds that the coefficient on the conditional variance is highest for the 2008-2009 global financial crisis period. Finally, Eroglu and Karaman (2018) examine the effect of monetary policy decisions by the Fed and the Central Bank of the Republic of Turkey (CBRT) on exchange rates, the term structure of interest rates, and credit default swap (CDS) rates. They find that both the Fed and CBRT decisions significantly affect the asset prices in Turkish financial markets.

Given the above literature, to the best of our knowledge, the only study that we know of that tries to analyze the impact of Fed policy decisions on the volatility of Turkish stock prices is the one by Celik et al. (2014). What makes our study different from their study is that we examine the impact of FOMC announcements on volatility persistence rather than on the level of volatility. Because of this, this study is also the first study in the literature that attempts to answer whether FOMC's decisions destabilize the stock prices in the Turkish stock market.

\section{Data and Methodology}

Our daily observations cover the period from January 4, 2000 to May 31, 2019. ${ }^{6}$ For the local market return, the BIST100 index is used, which includes all companies listed on the BIST100 except investment trusts. The BIST100 index returns are computed as the first difference of the log daily closing values in the local currency, adjusted for dividend payments and stocks splits. That is, let $P_{t}$ denote the price of the index at time $t$, then the market return at time $t$ is, $r_{t}=\log \left(P_{t} / P_{t-1}\right)$. The data for FOMC announcements are retrieved 
from Bloomberg terminal and used to investigate the effect of FOMC announcements on daily BIST100 index returns, and consequently, prices.

We are mainly interested in whether the FOMC announcement news has a destabilizing impact on the Turkish stock market. For example, volatility could go up because the information is coming to the market more quickly (which would not be destabilizing) or because investors are driving prices away from the fundamental value (which would be destabilizing). In order to capture whether prices/returns have been stabilized or destabilized, we need to know if they have been pushed away from fundamentals, or we need to look at the impact of FOMC announcements on volatility persistence rather than on the level of volatility.

To test for the persistence, we test for the level of asymmetry in the volatility of BIST100 index returns. Primarily, the level of persistence in volatility from bad news to good news is investigated, as asymmetric volatility comes from the fact that volatility is negatively correlated with lagged returns, a fact well-captured by the GJR specification of Glosten et al. (1993). In this study, we model the conditional variance by extending the GJR specification of Glosten et al. (1993) in such a way that FOMC announcements are accounted for. In our estimations of the daily market volatility, a procedure used by De Goeij and Marquering (2006) is employed.

The conditional volatility specification of our first extension follows:

$$
\begin{aligned}
& r_{t}=c+\varepsilon_{t} \\
& h_{t}^{2}=\omega+\omega^{a} I_{t}^{a}+b h_{t-1}^{2}+\left(\alpha_{p}+\gamma^{a} I_{t-1}^{a}\right) \varepsilon_{t-1}^{2}+\left(\alpha_{n}+\lambda^{a} I_{t-1}^{a}\right)\left(\varepsilon_{t-1}^{-}\right)^{2},
\end{aligned}
$$

we assume that $\varepsilon_{t} \mid \Phi_{t-1} \sim N\left(0, h_{t}^{2}\right)$, where $\Phi_{t-1}$ represents the information set at time $t-1 . r_{t}$ is the return on a XU100 index on date t. $h^{2}$ is the conditional variance of the unexpected return. $I^{a}$ is the indicator function whose values are determined based on the presence of the FOMC announcements: We have $l^{a}=1$ if there is FOMC news at time $t$ and 0 otherwise. ${ }^{7,8}$ Furthermore, $\varepsilon_{t-1}^{-}$is an $N \times 1$ vector with elements $\varepsilon_{t-1}^{-}=$ $\min \left[0, \varepsilon_{t-1}\right]$. The standart GJR model is imposed by imposing the restrictions $\omega^{a}=0, \gamma^{a}=0$ and $\lambda^{a}=0 .{ }^{9}$

The model predicts that on FOMC announcement days, the conditional volatility level differs from non-FOMC announcement days, which is measured by $\omega^{a}$. Conditional volatility is expected to be higher on FOMC announcement days since it is of tremendous importance to financial market participants. The parameter vectors $\gamma^{a}$ and $\lambda^{a}$ predict the effect of FOMC news on the conditional volatility of the following day. In this sense, the parameter $\gamma^{a}$ represents the effect of FOMC announcements on the volatility persistence. Finally, negative FOMC announcement news is allowed to be more persistent than positive FOMC news (reflected in $\lambda^{a}$ ).

The mean equation is estimated via OLS. The conditional volatility model parameters are estimated via the maximum likelihood. In order to provide convergence, as a preliminary method, initial parameter guesses are improved via the simplex method (free-derivative search procedure). Then Berndt, Hall, Hall, and Hausman (BHHH) algorithm (Berndt et al., 1974) is used as the primary estimation method. Student's tdistribution is used rather than the Gaussian error distribution due to the well known fat tail behavior in stock returns. Indeed, the fit of our model was improved with t-distributed errors. A considerably higher loglikelihood is found when the t-distributed errors are used compared to normal distributed errors.

Specification (1) assumes that the impacts of FOMC's announcements on the BIST100 index are the same over different periods of the stock market. As mentioned previously, investor reaction can be different in bull and bear market periods (see, for example, Hardouvelis \& Theodossiou, 2002). Thus, our model is specified that allows the effects of FOMC's announcements on return volatility to vary over different states of the market. To accomplish this, dummy variables are used that capture bull and bear periods. The model then follows the specification; 


$$
\begin{aligned}
& r_{t}=c+\varepsilon_{t}, \text { where } \varepsilon_{t} \mid \Phi_{t-1} \sim N\left(0, h_{t}^{2}\right) ; \\
& h_{t}^{2}=\omega+\omega^{\text {bear }} I_{t}^{a} \text { bear }_{t}+\omega^{\text {bull }} I_{t}^{a} \text { bull }_{t}+b h_{t-1}^{2} \\
& +\left(\alpha_{p}+\gamma^{\text {bear }} I_{t-1}^{a} \text { bear }_{t-1}+\gamma^{\text {bull }} I_{t-1}^{a} \text { bull } t_{t-1}\right)\left(\varepsilon_{t-1}^{+}\right)^{2} \\
& +\left(\alpha_{n}+\lambda^{\text {bear }} I_{t-1}^{a} \text { bear }_{t-1}+\lambda^{\text {bull }} I_{t-1}^{a} \text { bull }_{t-1}\right)\left(\varepsilon_{t-1}^{-}\right)^{2},
\end{aligned}
$$

where bear and bull are zero-one dummy variables for bear periods and bull periods, respectively. bear $_{t}=$ 1 is set if the equity market is in a bear market state at time $t$, and zero otherwise. In a similar vein, $b_{u l l}=1$ is set if the equity market is in a bull market state at time $t$, and zero otherwise. As can be seen in Equation (2), $\varepsilon_{t-1}^{+}=\max \left[0, \varepsilon_{t-1}\right]$ is also considered to distinguish negative shocks from positive ones; their impacts are analyzed separately.

To estimate the model in Equation (2), we follow a two-step procedure. In the first step, we employ a Markow-Switching regression to extract the bear and bull periods. In the second step, we run the GARCHGJR model enhanced with the market status dummies. In this regard, we elaborate the Switching regression as follows:

As stated in Section 2, local returns $r_{t}$ are calculated as the first difference of the logged daily price index, adjusted for dividend payments. A Markov switching model of equity returns can be written as:

$$
\phi(L) R_{t}=\mu\left(S_{t}\right)+\varepsilon_{t} ; \quad \varepsilon_{t} \sim \text { i.i.d. } N\left(0, \sigma_{S_{t}}^{2}\right),
$$

where $\varphi(L)=1-L-L^{2}-\cdots-L^{k}$ and $L$ is the lag operator. Terms $\mu\left(S_{t}\right)$ and $\sigma_{S_{t}}^{2}$ are the mean and variance of $r_{t}$ as functions of the state variable $S_{t} . S_{t}$ is an unobserved latent dummy variable that reflects the state of the market where $S_{t}=0$ indicates that the stock market is in a bull phase, and $S_{t}=1$ that it is in a bear phase. The state variable is assumed to follow a two-state Markov chain with fixed transition probability matrix:

$$
P=\left(\begin{array}{cc}
p^{00} & 1-p^{00} \\
1-p^{11} & p^{11}
\end{array}\right)
$$

where

$$
\begin{aligned}
& p^{00}=P\left(S_{t}=0 \mid S_{t-1}=0\right) \\
& p^{11}=P\left(S_{t}=1 \mid S_{t-1}=1\right) .
\end{aligned}
$$

The lag order is chosen as zero, according to Schwarz's information criterion. ${ }^{10}$ Thus, an MS-AR(0) model is chosen as our simple mean/variance Markov switching model. Similar to other studies (see for example; Maheu \& McCurdy 2000, and Chen, 2009) bull market regime is identified with a higher mean and lower variance, and the bear market regime is identified with a lower mean and greater variance.

The parameters of the MS model and the transition probabilities are estimated via the maximum likelihood estimation procedure using a backward recursive algorithm, following Kim (1994). Simply 0.5 as the cut-off value is taken for $S t=0$ or 1 , and the smoothed probabilities are used to infer bull and bear markets. That is, a period with smoothed probabilities of $S t=0$ greater than (less than) 0.5 is defined as a bull (bear) market and we set bear $_{t}=1\left(\right.$ bull $\left._{t}=1\right)$.

The bull and bear periods in the BIST100 index are clear from our Markov switching model. The transition probabilities show that bear and bull market states are quite persistent. The bull market regime is 
found to persist on average for $\left(1 / 1-p^{00}\right)=86$ months while the bear market regime is found to persist an average of $\left(1 / 1-p^{11}\right)=41$ months.

As can be seen in Figure 1, the calculated bull market probabilities match the BIST100 index quite well. A bull market is identified almost continuously from early 2004 to 2019, except for the fall during the global financial crisis of 2007-2008. These results accord with Chen (2007), who documented that Markov switching methodology works quite well in the US market.

According to the US National Bureau of Economic Research, the great recession began in December 2007 and ended in June 2009, and thus extended over eighteen months. When looking at our exact date our Markov model identified for bear periods in ISE, we see that the bear period began in December 2007 and lasted until May 2009. This is striking, given that it seems to overlap perfectly. We view this as an important feature of our model since whether the stock market is in a bear period or a bull period at any given time is crucial information for all investors around the globe. Especially, identifying the start of a bear period correctly may help investors to take necessary precautions for themselves.

Graph 1. BIST100 Index and Bull Market Probabilities

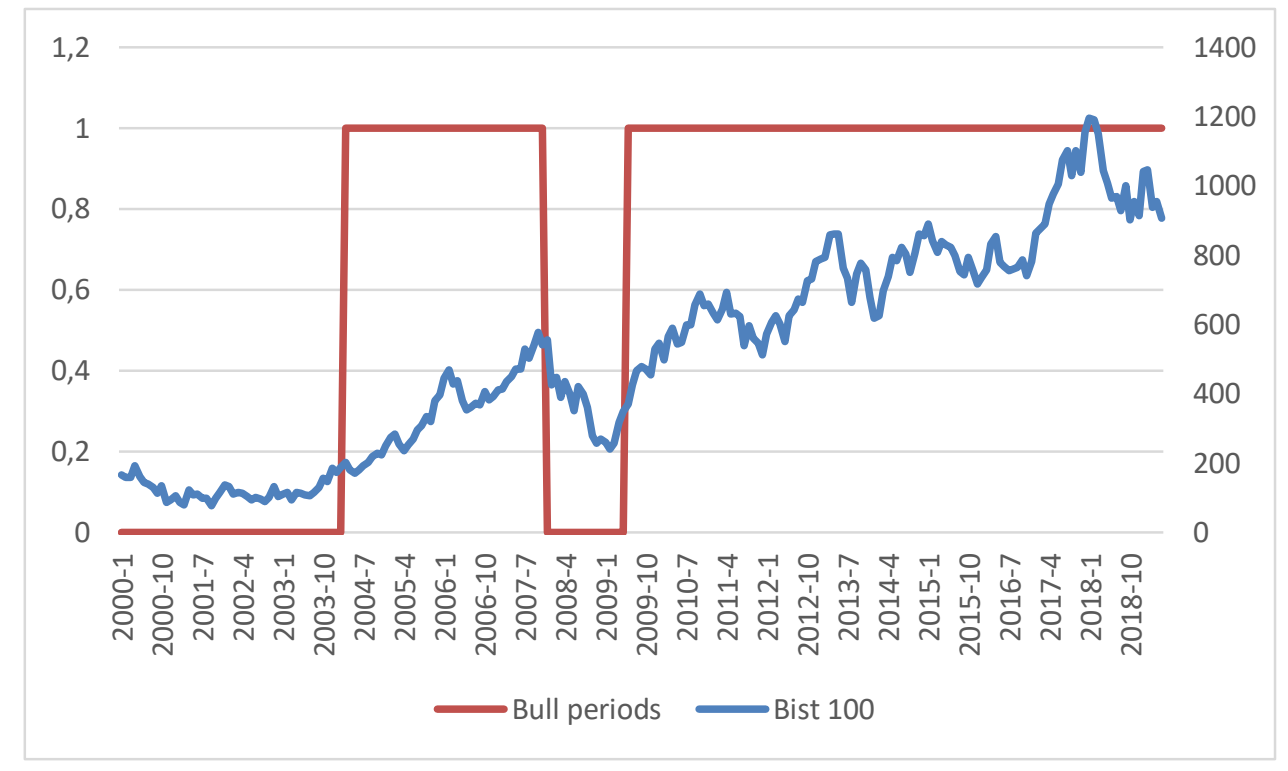

\section{Preliminary Analysis}

As our preliminary analysis, the summary statistics for the daily log-returns of the BIST100 index are presented in Table 1. It may be observed that the mean of returns on FOMC's announcement days is higher than those of non-FOMC's announcement days. Measurements both in the absolute value of the returns and square of the returns show that BIST100 volatility is higher on announcement dates than on nonannouncement dates. However, it can also be seen that the range of returns (the difference between the maximum and minimum returns) is larger during non-announcement days than they are during announcement days. We also present summary statistics for FOMC Announcement days in Table 2. It can easily be seen that there are 87 and 68 days for good and bad announcements, respectively.

Moreover, our analysis points out an asymmetry in the persistence of volatility from bad news versus good news. The inclusion of bear and bull dummy variables, which capture the effects of the FOMC's announcement on return volatility during different states of the market, is also found to produce an increase in log-likelihood. This situation, in turn, justifies the need for using the different states of the market during FOMC's announcements as a control variable in the volatility equation. The details of our findings are presented in the next section. 
The Impact of US Monetary Policy Announcements on Equity Prices: Evidence from Borsa Istanbul

Table 1. Summary Statistics for the BIST100 Index Open-Close Returns

\begin{tabular}{|c|c|c|c|c|c|c|c|c|c|}
\hline \multirow[b]{3}{*}{ Mean } & \multicolumn{3}{|c|}{$\frac{\text { Full Sample }}{(4856)}$} & \multicolumn{3}{|c|}{$\frac{\text { FOMC Announcement Days }}{(155)}$} & \multicolumn{3}{|c|}{$\frac{\text { Non-Announcement Days }}{(4701)}$} \\
\hline & $\mathrm{Rt}$ & $\left|R_{t}\right|$ & $\mathrm{R}_{\mathrm{t}}^{2}$ & $\mathrm{Rt}$ & $\left|R_{t}\right|$ & $\mathrm{R}_{\mathrm{t}}^{2}$ & $\mathrm{Rt}$ & $\left|R_{t}\right|$ & $\mathrm{R}_{\mathrm{t}}^{2}$ \\
\hline & 0.0004 & 0.0145 & 0.0004 & 0.0028 & 0.0187 & 0.0006 & 0.0003 & 0.0144 & 0.0004 \\
\hline Median & 0.0008 & 0.0104 & 0.0001 & 0.0026 & 0.0146 & 0.0002 & 0.0008 & 0.0103 & 0.0001 \\
\hline Max & 0.1777 & 0.1998 & 0.0399 & 0.1179 & 0.1179 & 0.0139 & 0.1777 & 0.1998 & 0.0399 \\
\hline Min & -0.1998 & 0 & 0 & -0.0706 & 0.0002 & 0 & -0.1998 & 0 & 0 \\
\hline Std.Dev. & 0.021 & 0.0152 & 0.0014 & 0.02517 & 0.017 & 0.0014 & 0.0208 & 0.0151 & 0.0014 \\
\hline
\end{tabular}

Rt denotes log return of the XU100 index at time $t,\left|R_{t}\right|$ denotes the absolute log return of the XU100 index at time $t$ and $R_{t}{ }^{2}$ denotes squared log return of the XU100 index at time t. Our sample period includes 4856 observations. 155 of these 4856 observations correspond to FOMC announcement days. The rest part of the observations, there are 4701 days, correspond ton on-announcement days.

Table 2. Summary Statistics for FOMC Announcement Days

FOMC Announcement Days

\begin{tabular}{l|c|c|}
\multicolumn{1}{c|}{} & $\frac{\text { Bad news }}{(68)}$ & $\frac{\text { Good news }}{(87)}$ \\
\hline Mean & -0.018140 & 0.019085 \\
Median & -0.016772 & 0.013894 \\
Maximum & -0.000257 & 0.117941 \\
Minimum & -0.070585 & 0.000166 \\
Std. Dev. & 0.014581 & 0.018804 \\
\hline
\end{tabular}

\subsection{Results}

Our first results are presented in Table 3, which is based on specification (1). At first glance, it can easily be seen that the ARCH and GARCH effects are positive and highly significant. Strong asymmetric effects $\left(\alpha \_n\right)$ are found in volatility persistence. Our model indicates that conditional volatility seems to increase more after a large negative shock ( $\left.\alpha \_p+\alpha \_n\right)$, then a largely positive one $\left(\alpha \_p\right)$. Conditional volatility is also found to be higher on FOMC's announcement days, which is consistent with our prediction. The estimated coefficient for the dummy on FOMC's announcement days $\left(\omega^{\wedge} \mathrm{a}\right)$ is high and statistically significant. This indicates the increased risk in the Turkish equity market on days with FOMC's announcements.

Some previous studies (See, for example, Engle \& Li, 1998) document that macroeconomic news decreases information asymmetry after disclosure. With this perspective, features of FOMC's news would make the "learning" process shorter than any kind of private or public information. Thus, the persistence of volatility from FOMC's announcement days is expected to be smaller than that from non-FOMC's announcement days.

When looking at Table 3, no evidence is found for FOMC's news that it had a destabilizing impact on the Turkish stock market. None of the interaction terms is significant. Both ARCH coefficients $\left(\gamma^{a}\right.$ and $\left.\lambda^{a}\right)$ on FOMC's announcement days are insignificant and enter with negative signs. FOMC's announcement-day volatility would appear not to persist at all and thus to have no impact on conditional volatility of the following day. In addition, FOMC's news also seems not to affect asymmetric volatility in the BIST100 index.

After having presented the effect of FOMC's news on the volatility of the BIST100 index, as noted in Section 3, now the impact of FOMC's news over different states of the stock market is analyzed. To this end, the states of the stock market are classified as "bear" and "bull" by means of using the Markov switching 
model. Table 4 presents the effect of FOMC's news on the volatility of the BIST100 index during "bear" and "bull" markets. Conditional volatility is found to be higher on FOMC's announcement days either in bear $\left(\omega^{\text {bear }}\right)$ or in bull markets $\left(\omega^{\text {bull }}\right)$ compared to non-FOMC's announcement days $(\omega)$. Besides, FOMC's announcements in bear periods $\left(\omega^{\text {bear }}\right)$ are found to have a larger impact on daily volatility compared to FOMC's announcements in bull periods $\left(\omega^{\text {bull }}\right)$.

Table 3. FOMC's Announcements and Asymmetric Volatility in the BIST100 Index

\begin{tabular}{ccc|rc}
\hline \hline & $\begin{array}{c}\text { Coefficient } \\
\text { Estimates }\end{array}$ & Std. Error & $\begin{array}{c}\text { Nyblom test } \\
\text { statistic }\end{array}$ & p-value \\
\hline $\boldsymbol{\omega}$ & $0.0000029^{* * *}$ & 0.000001 & 1.57689 & 0 \\
$\boldsymbol{\omega}^{\boldsymbol{a}}$ & $0.000058^{* * *}$ & 0.000021 & 1.313011 & 0 \\
$\boldsymbol{b}$ & $0.9094^{* * *}$ & 0.0084 & 2.063569 & 0 \\
$\boldsymbol{\alpha}_{\boldsymbol{p}}$ & $0.0495^{* * *}$ & 0.0092 & 2.501512 & 0 \\
$\boldsymbol{\alpha}_{\boldsymbol{n}}$ & $0.06451^{* * *}$ & 0.0129 & 1.997469 & 0 \\
$\boldsymbol{\gamma}^{\boldsymbol{a}}$ & -0.0361 & 0.032 & 1.313011 & 0 \\
$\boldsymbol{\lambda}^{\boldsymbol{a}}$ & -0.0589 & 0.0607 & 0.213785 & 0.24 \\
\hline \multicolumn{2}{c}{} & 12827 & Joint Test Statistic & p-value \\
\hline \hline
\end{tabular}

This table shows the estimation results for Equation (1). The sample period starting from January 2000 to May 2019 includes 4856 observations. On the left panel, coefficient estimates are shown with their respective standard errors. $L(\theta)$ denotes the loglikelihood for the estimated model. *** indicates significance at $1 \%, * *$ indicates significance at $5 \%$, and $*$ indicates significance at $10 \%$. On the right panel, we present Nyblom (1989) stability test results for each parameter and the overall model. P-value is the $p$-value of this test.

Table 4. FOMC's Announcements and Asymmetric Volatility in the BIST100 Index During the Bull and Bear Periods of the Turkish Stock Market

\begin{tabular}{|c|c|c|c|c|}
\hline & $\begin{array}{c}\text { Coefficient } \\
\text { Estimates }\end{array}$ & Std. Error & $\begin{array}{c}\text { Nyblom test } \\
\text { statistic }\end{array}$ & p-value \\
\hline$\omega$ & $0.000005^{* * *}$ & 0.0000 & 1.4225 & 0 \\
\hline$\omega^{\text {bear }}$ & $0.00042 * * *$ & 0.0001 & 0.2669 & 0.16 \\
\hline$\omega^{b u l l}$ & $0.000041^{* * *}$ & 0.0000 & 0.5568 & 0.03 \\
\hline $\boldsymbol{b}$ & $0.9058^{* * *}$ & 0.0091 & 1.3713 & 0 \\
\hline$\alpha_{p}$ & $0.037^{* * *}$ & 0.0089 & 1.5489 & 0 \\
\hline$\alpha_{n}$ & $0.1053^{* * *}$ & 0.0111 & 1.1517 & 0 \\
\hline$\gamma^{\text {bear }}$ & 0.0323 & 0.1000 & 0.0084 & 1 \\
\hline$\gamma^{\text {bull }}$ & $-0.057^{* *}$ & 0.0273 & 0.0535 & 0.85 \\
\hline$\lambda^{\text {bear }}$ & -0.129 & 0.1810 & 0.1115 & 0.51 \\
\hline \multirow[t]{3}{*}{$\lambda^{\text {bull }}$} & $-0.0972^{*}$ & 0.0592 & 0.0303 & 0.97 \\
\hline & $L(\theta)$ & 12843 & $\begin{array}{l}\text { Joint Test } \\
\text { Statistic }\end{array}$ & $p$-value \\
\hline & & & 3.47274 & 0.01 \\
\hline
\end{tabular}

This table shows the estimation results for Equation (2). The sample period starting from January 2000 to May 2019 includes 4856 observations. On the left panel coefficient estimates are shown with their respective standard errors. $L(\theta)$ denotes the log-likelihood for the estimated model. *** indicates significance at $1 \%, * *$ indicates significance at $5 \%$ and $*$ indicates significance at $10 \%$. On the right panel, we present Nyblom (1989) stability test results for each parameter and the overall model. P-value is the $p$-value of this test. 
In order to capture whether prices/returns have been stabilized or destabilized, we need to look at the impact of FOMC announcements on volatility persistence rather than on the level of volatility. With this perspective, signs of the interaction terms $\left(\gamma^{\text {bear }}, \gamma^{\text {bull }}, \lambda^{\text {bear }}\right.$, and $\left.\lambda^{\text {bull }}\right)$ are of great importance. When looking at the persistence of volatility from FOMC's announcement days for bear and bull periods separately, no evidence is found that FOMC's news had a destabilizing impact on the BIST100 index. On the contrary, both positive announcement shocks $\left(\gamma^{\text {bull }}\right)$ and negative announcement shocks ( $\left.\lambda^{\text {bull }}\right)$ in bull periods are found to depress volatility on consecutive days. ${ }^{11}$ Both interaction terms enter with negative signs and are highly significant. In other words, FOMC's announcements in bull periods have a stabilizing role rather than destabilizing in BIST.

To show the statistical significance of the above findings, we test the following three hypotheses: 1 ) $H_{0,1}: \omega^{a}=\lambda^{a}=\gamma^{a}=0$ (in Equation (1)), 2) $H_{0,2}: \omega^{\text {bear }}=\omega^{\text {bull }}=\lambda^{\text {bear }}=\lambda^{\text {bull }}=\gamma^{\text {bear }}=\gamma^{\text {bull }}=0($ In Equation (2)) and 3) $H_{0,3}: \omega^{* \text { bear }}=\lambda^{* \text { bear }}=\gamma^{* \text { bear }}=0$ (in Equation (7)), where we recover the parameters in the last hypothesis from Equation (7). Moreover, we require the restricted model given in Equation (8)

$$
\begin{aligned}
& r_{t}=c+\varepsilon_{t} \\
& h_{t}^{2}=\omega+\omega^{a} I_{t}^{a}+\omega^{* \text { bear }} I_{t}^{a} \text { bear }_{t}+b h_{t-1}^{2}+\left(\alpha_{p}+\gamma^{a} I_{t-1}^{a}+\gamma^{* \text { bear }} I_{t-1}^{a} \text { bear }_{t-1}\right) \varepsilon_{t-1}^{2} \\
& +\left(\alpha_{n}+\lambda^{a} I_{t-1}^{a}+\lambda^{* \text { bear }} I_{t-1}^{a} \text { bear }_{t-1}\right)\left(\varepsilon_{t-1}^{-}\right)^{2} . \\
& r_{t}=c+\varepsilon_{t} \\
& h_{t}^{2}=\omega+b h_{t-1}^{2}+\alpha_{p} \varepsilon_{t-1}^{2}+\alpha_{n}\left(\varepsilon_{t-1}^{-}\right)^{2} .
\end{aligned}
$$

Notice that Equation (2) and (7) are essentially the same regression equation after some reparametrization, and they yield the same maximized log-likelihood. However, we need this new Equation to depict a presentation of Equation (2), which is a nested model of Equation (1). We can test these hypotheses with the Likelihood ratio method since Equation (1) and (2) nests Equation (8), and Equation (7) nests Equation (1).

Before we proceed to demonstrate the test results, we first elaborate these hypotheses. If the first hypothesis $H_{0,1}$ is true, then we say that there is no impact of the policy announcements on stock price volatility, ceteris paribus. Furthermore, under the second hypothesis $H_{0,2}$ we say that the interacted effect of the policy announcement and market status on the volatility is not meaningful. Finally, under the last hypothesis $H_{0,3}$ there is no market status effect on the volatility, while the policy announcement influence is active. From Table 5, we can deduct that all three hypotheses are rejected under the $1 \%$ significance level. Accordingly, both the policy announcement and market status effects on the volatility is statistically present in the data.

Table 5. The Results of the Likelihood Ratio Tests

\begin{tabular}{ccccc}
\hline \hline Hypothesis & LR. & p-value & Crit. Val. & df \\
\hline$H_{0,1}$ & 14 & 0.0029 & 7.814728 & 3 \\
$H_{0,2}$ & 47.7946 & 0.0000 & 12.59159 & 6 \\
$H_{0,3}$ & 33.7946 & 0.0000 & 7.814728 & 3 \\
\hline \hline
\end{tabular}

Note: LR denotes the Likelihood Ratio Statistic $L R=-2\left(L_{r}(\theta)-\right.$ $L_{u}(\theta)$, where $L_{r}(\theta)$ is the likelihood under the null hypothesis and $L_{u}(\theta)$ is the likelihood of the unrestricted model. The $p$-value is the $\mathrm{p}$-value of the likelihood ratio test, Crit. Val. is the critical value under the null hypothesis. This critical value can be derived from the $\% 95$ quantile of $\chi^{2}(d f)$ distribution. 
We also employ Nyblom's (1989) parameter stability test. This test fits our analysis since it allows nonlinear functional forms for the regression equation. The test results for each model can be found on the right panel of Table 3 and 4. On the one hand, we observe that the model without market status Dynamics exhibit more instability, since for only $\lambda^{a}$ we cannot reject the null of parameter stability. On the other hand, the model with market status Dynamics possesses fewer parameters exhibiting instability. Especially, regime specific parameters are stable through time at $1 \%$ significance level. Moreover, we glance at overall stability, the first model (Equation (1)) is statistically unstable, while the second model (Equation (2)) is statistically stable at $1 \%$ significance level.

\section{Conclusion}

FOMC's news is generally accepted as one of the most important news in the world's financial markets. This importance stems from a significant effect of FOMC's news on global liquidity condition, which is thought to be the main driver of capital flows to emerging markets (See, for example, Chandrashekhar, 2008 and Shin, 2013). The risk appetite of international investors is strongly affected by the global liquidity condition, which in turn is affected by the US interest rates. Therefore, FOMC's decisions are thought to attract the attention of many international investors in emerging markets. A sizeable European emerging market, Turkey, is chosen to analyze due to specific characteristics of the Turkish economy.

A longstanding specific characteristic of the Turkish economy is a low savings rate. The Turkish economy has to rely on capital inflows in order to sustain high growth rates in its economy. On this basis, the Turkish economy is thought to be very fragile towards these capital flows. While the benefit of the capital flows on the Turkish economy is widely documented (see, for example, Celasun et al., 1999, Kirmanoglu \& Ozcicek, 1999, and Berument, 2004), reversals in capital flows also led to severe financial crises (1994, 2001 and 2008-2009) in the Turkish economy. These crises revealed the financial dependence of Turkey on international portfolio flows.

With the perspective mentioned above, this study investigates if FOMC's announcements have a destabilizing effect on stock prices in the BIST100 index. Our first results show that conditional daily volatility tends to rise on FOMC's announcement days, but there is no evidence of an increase in conditional volatility on consecutive days. In other words, no evidence is found that FOMC's announcements have a destabilizing effect on the Turkish stock market.

When looking at the effect of FOMC's announcements on the volatility of the BIST100 index over different states of the stock market, conditional volatility on FOMC's announcement days, both in bull periods and bear periods, are found to be higher than that on non-FOMC's announcement days. These results are also similar to those of Celik et al. (2009), who find that an increase in policy rates decreases the volatility of sessions in ISE. However, when investigating the persistence of volatility from FOMC's announcement days for bear and bull periods separately, no evidence of destabilizing impact is found for FOMC's news. Quite the contrary, both positive announcement and negative announcement shocks in bull periods are found to depress volatility on consecutive days. In other words, FOMC's announcements in bull periods have a stabilizing effect rather than a destabilizing one in Borsa Istanbul.

\section{Disclosure Statements}

1. The authors of this article confirm that their work complies with the principles of research and publication ethics.

2. No potential conflict of interest was reported by the authors.

3. This article was screened for potential plagiarism using a plagiarism screening program. 


\section{End Notes}

1. See https://focus. world-exchanges.org/issue/december-2018/market-statistics_date of access, September 23, 2020.

2. Turkish Balance of Payments statistics are reported on a monthly basis by The Central Bank of the Republic of Turkey.

3. For a current account balance as a \% of GDP for all countries, see https://data.worldbank.org/indicator/BN.CAB.XOKA.GD.ZS?locations=TR_date of access, September 23, 2020.

4. Previous studies observed that large negative returns tend to increase volatility than do positive returns of the same magnitude. This is called "the leverage effect" observed in equity returns. With GJR-GARCH model, the conditional variance is allowed to respond differently to the past negative and positive innovations.

5. According to the Dividend Discount Model, share prices should be based on the sum of the expected future dividend flows, discounted back to the present. Thus, Monetary policy news can affect equity prices in two ways. Either through future cash flows (dividends) of equities or discount rates.

6. Due to the changing nature of globalization we don't prefer the longest possible data, since it can be contaminated by old and possibly no-longer relevant returns. Our data includes the last twenty years of returns which starts in January 2000. Our period also covers the 2000-2001 financial crisis in Turkey and the global financial crisis of 20082009.

7. We looked at whether there are other macroeconomic releases which coincide with the FOMC announcement days, but find no systematic macroeconomic releases on the same days. This would also be true if there were two or three macroeconomic announcement releases which are concurrent with the FOMC announcements. We would atribute this to noise, since we have 155 FOMC announcement days.

8. We would examine the effects of FOMC announcements potentially in a better way If we obtained FOMC announcement surprises. Surprise variable is defined as the difference between the announced target for the federal funds rate and expectations derived from the federal funds futures contract (Kuttner, 2001). The target surprise can be computed as the change in the current-month federal funds futures contract rate in a thirty-minute window around the FOMC announcement (Wongswan, 2009). We couldn't obtain these data, due to its high cost. We, thus, employ announcement dummy variable rather than the announcement surprise itself which is similar to those of De Goeij and Marquering (2006) who examine the impact of US macroeconomic announcements on the conditional volatility of bond returns.

9. The number of lags was chosen according to Akaike's Information Criterion (AIC) and Schwarz's Information Criterion (SIC).

10. For a useful discussion on this topic, see Francis X. Diebold, Elements of Forecasting, $2^{\text {nd }}$ ed. South Western Publishing, 2001, pp. 83-89. On balance, Diebold recommends the SIC criterion.

11. We distinguish negative shocks from positive ones to investigate their effects separately.

\section{References}

Andersen, T., Bollerslev, T., Diebold, F., \& C. Vega. (2007). Real-time price discovery in stock, bond and foreign exchange markets. Journal of International Economics, 73, 251-277

Berndt, E. R., Hall, B. H., Hall, R. E., \& Hausman, J. A. (1974). Estimation and inference in nonlinear structural models. Annals of Economic and Social Measurement, 3(4), 653-665.

Berument, H., \& Dincer, N. (2004) Do capital flows improve macroeconomic performance in emerging markets?: The Turkish experience. Emerging Markets Finance and Trade, 40, 20-32.

Bowman, G. R., Robin, A. J., \& Weintrop, J. (1995). The robustness of event study methodologies to varying market conditions. Working paper, Auckland University.

Celasun, O., Denizer, C., \& He, D. (1999). Capital flows, macroeconomic management, and the financial system. Turkish Case, 1989-97. World Bank Working Paper, Washington, DC.

Chandrashekhar, C. P. (2008). Global liquidity and financial flows to developing countries: New trends in emerging markets and their implications. G24 Discussion Paper Series No. 52, UNCTAD.

Chen, S. S. (2007). Does monetary policy have asymmetric effects on stock returns? Journal of Money, Credit and Banking, 39(2-3), 667-688.

Chen, S. S. (2009). Predicting the bear stock market: Macroeconomic variables as leading indicators. Journal of Banking and Finance, 33, 211-223. 
Çelik, Ş., Erer, D., Erer, E., \& Güleç, T. C. (2015). TCMB para politikası kararlarındaki değişimlerin ve TCMB, FED ve ECB sözlü yönlendirmelerin BIST 100 oynaklığı üzerindeki etkisinin analizi. Maliye Finans Yazıları, (103), 51-84.

De Goeij, P., \& Marquering, W. (2006). Macroeconomic announcements and asymmetric volatility in bond returns. Journal of Banking \& Finance, 30(10), 2659-2680.

Diebold, F. X. (2001). Elements of forecasting. South Western Publishing.

Docking, D. S., \& Koch, P. D. (2005). Sensitivity of investor reaction to market direction and volatility: Dividend change announcements. Journal of Financial Research, 28(1), 21-40.

Ehrmann, M., \& Fratzscher, M. (2009). Global financial transmission of monetary policy shocks. Oxford Bulletin of Economics and Statistics, 71(6), 739-759.

Engle, R. F. (1998). Macroeconomic announcements and volatility of treasury futures. Discussion Paper 98-27.

Eroğlu, B. A., \& Karaman, S. Y. (2018). Responses of the term structure of interest rates and asset prices to monetary policy shocks: Evidence from Turkey. METU Studies in Development, 45(2), 117-158.

Flannery, M. J., \& James, C. M. (1984). The effect of interest rate changes on the common stock returns of financial institutions. The Journal of Finance, 39(4), 1141-1153.

Frankel, J., \& Roubini, N., (2001). The role of industrial country policies in emerging market crises. NBER Working Paper No. 8634 .

Glosten, L. R., Jagannathan, R., \& Runkle, D. E. (1993). On the relation between the expected value and the volatility of the nominal excess return on stocks. The Journal of Finance, 48(5), 1779-1801.

Goldberg, L. S. (2002). When is US bank lending to emerging markets volatile? In Preventing currency crises in emerging markets (pp. 171-196). University of Chicago Press.

Hausman, J., \& Wongswan, J. (2011). Global asset prices and FOMC announcements. Journal of International Money and Finance, 30(3), 547-571.

Hayo, B., Kutan, A. M., \& Neuenkirch, M. (2012). Federal reserve communications and emerging equity markets. Southern Economic Journal, 78(3), 1041-1056.

Hussain, S. M. (2011). Simultaneous monetary policy announcements and international stock markets response: An intraday analysis. Journal of Banking and Finance, 35(3), 752-764.

Ikizlerli, D. (2019). Institutional investors and stock market volatility. Evidence from Korea. Applied Economics Letters, 23(4), 1-4.

Kim, C. J. (1994). Dynamic linear models with Markov-switching. Journal of Econometrics, 60(1-2), 1-22.

Kim, S. (2001). International transmission of US monetary policy shocks: Evidence from VAR's. Journal of Monetary Economics, 48(2), 339-372.

Kirmanoglu, H., \& Ozcicek, O. (1999). The effect of short-term capital inflow on the Turkish economy. Yapi Kredi Economic Review, 10(1), 27-34

Klein, A., \& Rosenfeld, J. (1987). The influence of market conditions on event-study residuals. Journal of Financial and Quantitative Analysis, 22(3), 345-351.

Kodres, L. E., \& Pritsker, M. (2002). A rational expectations model of financial contagion. The Journal of Finance, 57(2), 769-799.

Konrad, E. (2009). The impact of monetary policy surprises on asset return volatility: The case of Germany. Financial Markets and Portfolio Management, 23(2), 111-135.

Koylu, K. M., \& Yucel, A. (2019). Amerikan Merkez Bankası faiz kararları Ille BIST 100 endeksi arasındaki ilişkinin belirlenmesi. Muhasebe ve Finansman Dergisi, (84), 165-176.

Maheu, J. M., \& McCurdy, T. H. (2000). Identifying bull and bear markets in stock returns. Journal of Business \& Economic Statistics, 18(1), 100-112.

Nyblom, J. (1989). Testing for the constancy of parameters over time. Journal of the American Statistical Association, 84(405), 223-230.

Phylaktis, K., 2006. Emerging markets finance: Overview of the special issue. Journal of International Money and Finance, 25, 349-357.

Robitaille, P. T., \& Roush, J. E. (2006). How do FOMC actions and US macroeconomic data announcements move Brazilian sovereign yield spreads and stock prices? FRB International Finance Discussion Paper, (868). 
Shin, H. S. (2013). The second phase of global liquidity and its impact on emerging economies. Proceedings, Federal Reserve Bank of San Francisco, issue Nov, 1-10.

Valente, G. (2009). International interest rates and US monetary policy announcements: Evidence from Hong Kong and Singapore. Journal of International Money and Finance, 28(6), 920-940.

Wongswan, J. (2006). Transmission of information across international equity markets. The Review of Financial Studies, 19(4), 1157-1189.

Wongswan, J. (2009). The response of global equity indexes to US monetary policy announcements. Journal of International Money and Finance, 28(2), 344-365. 